\title{
Culturally Responsive Instructional Leadership: A Conceptual Exploration with Principals of Three New Zealand Mainstream Schools
}

\author{
Vincent M. Mugisha \\ University of Vermont \\ U. S. A.
}

Principals of many New Zealand (NZ) mainstream schools navigate a complex intercultural educational policy environment to address the academic challenges of Māori and Pasifika students. This inquiry sought to explore the concept of culturally responsive instructional leadership by studying the knowledge, actions, motives, perceptions, and challenges of White principals in a primary school, an intermediate school, and a high school in NZ. The emergent conceptual definition of culturally responsive instructional leadership includes those purposeful, well-intentioned, creative, and collaborative actions that a principal takes to enhance the academic engagement and achievement of minority-culture students.

\author{
Socio-Political Context \\ Educational Policy Context \\ Conceptualizing the Inquiry \\ Methodology \\ Findings \\ Discussion and Conclusion \\ Notes \\ References
}

\section{Socio-Political Context}

Founded in 1840 on the basis of the Treaty of Waitangi signed between the British Crown and Māori chiefs on behalf of the Tangata Whenua (the indigenous people of the land), present-day New Zealand (NZ) officially identifies with ideals of biculturalism ${ }^{1}$ (Sibley, Robertson, \& Kirkwood, 2005). Since the 1970s when industrialization policy sought a bountiful supply of unskilled and semiskilled labor, immigration of various Pasifika ethnic groups to NZ has grown by leaps and bounds (Hill, 2010). With additional immigration of mainly skilled Asian workers in the last 25-30 years, NZ has burgeoned into a multicultural and multilingual society that threatens to supplant the official identity of biculturalism (Smith, 2010). The effects of these immigration patterns reflected in the last population census place Asian ethnic groups at 9.2\% and Pasifika groups at $6.9 \%$, while the indigenous Māori people and Pākehā (New Zealanders of European descent) remain at $14.6 \%$ and $67.6 \%$ respectively (Statistics New 
Zealand, 2006). These demographics have important implications for NZ's educational policy.

\section{Educational Policy Context}

NZ's public education system has evolved from deliberate implementation of colonial assimilation policies, which were responsible for a rapid decline in Māori language and culture, to the support of bicultural and bilingual education programs starting in the 1970s (Bishop, 2003; May \& Hill, 2005). Presently the NZ school system is composed of mainstream schools offering an Englishmedium curriculum and parallel Māori and Pasifika immersion and bilingual schools with varying levels of mixing English and Māori or Pasifika languages (Ministry of Education, MOE, 2009).

Despite these policy changes that favor the rejuvenation of Māori culture and the survival of new minority cultures, $85 \%$ of Māori students and the vast majority of Pasifika students attend mainstream schools (Tuuta, Bradnam, Hynds, Higgins, \& Broughton, 2004) for which a new national curriculum was introduced in 2007. Although the new curriculum (MOE, 2007) explicitly encouraged the pursuit of Treaty of Waitangi objectives through Māori history as well as the inclusion of Māori cultural practices in mainstream schools (Smits, 2011), it offered no directives for equitable teaching of English and Māori, NZ's official spoken languages. However, it required mainstream schools to teach an additional or second language with a particular focus on students in years 7-10. In this case, an additional language could be Māori, a Pasifika language, or an international non-Polynesian language such as French, German, Chinese, or Japanese.

Although attendance at mainstream schools continues to be popular among Māori and Pasifika students, studies have confirmed the persistence of educational disparities in these schools (Bishop, 2003; Bishop, Berryman, Cavanagh, \& Teddy, 2009; Tuuta, Bradnam, Hynds, Higgins, \& Broughton, 2004). In 2009, as a case in point, while the Pākehā students' suspension rate was four per 1,000 students, the same rate was about seven and over 14 for Pasifika and Māori students respectively (MOE, 2009).

Furthermore, Māori students are persistently overrepresented in high school-leaving rates with fewer qualifications such as the National Certificates of Educational Achievement (NCEA). NCEA, the main national qualification for secondary school students, is offered at three levels during the final three years of high school, recognized by employers, and used for selection by universities and polytechnics both in NZ and overseas (NZ Qualifications Authority, 2013). Educational statistics (MOE, 2009) continue to show racial-ethnic disparities in these qualifications: $75 \%$ of Pākehā, $65 \%$ of Pasifika, and $50 \%$ of Māori students left high school with an NCEA level II qualification or above in 2008. While these statistics indicate that Pasifika students are performing better than Māori students, other studies have also confirmed that Pasifika students underachieve in literacy and exhibit disengagement and alienation at school (Alton-Lee; \& 
Flockton \& Crooks as cited in Fletcher, Parkhill, Fa'afoi, Taleni, \& O'Regan, 2009).

MOE (2009) has also acknowledged these inequities by stating, "The education system is not achieving the success it should with all NZ's ethnic groups" (p. 39). To address these achievement disparities, MOE consequently launched two strategies. The first strategy was a five-year policy known as the Ka Hikitia_-Managing for Success: The Māori Education Strategy 2008-2012 (MOE, 2009), which defined MOE's "approach to achieving education success for, and with, Māori" (p. 39). The second strategy was a four-year policy known as the Pasifika Education Plan 2009-2012 (MOE, 2009), which "established goals and strategies for the engagement and achievement of Pasifika learners" (p. 39). These two policies were handed down to mainstream schools for consideration in instructional processes. At the end of 2012, the Education Ministry expressed strategic intentions to reauthorize both the Ka Hikitia strategy (MOE, 2012a) and the Pasifika Education Plan (MOE, 2012b).

Ethnic disparities in NZ's education system are not only prevalent at the student level. They have also persisted amongst teachers; at least $79 \%$ of the teaching force in mainstream primary, intermediate, and high schools ${ }^{3}$ are of Anglo-European descent (Howard, 2010). This phenomenon may raise concerns of cultural competency in instruction (Diller \& Moule, 2005) for Māori and Pasifika students. In line with these concerns, research has found that teachers in NZ's mainstream schools take the low scholastic achievement of ethnic minority students for granted and consider it as normal and beyond their powers (Bishop, Berryman, Cavanagh, \& Teddy, 2009). To help change these attitudes, especially about Māori learners, MOE has been supporting the implementation in select schools of Te Kotahitanga, which is a research and professional development project that seeks to improve the educational achievement of Māori students in mainstream secondary schools through culturally responsive instruction (Bishop et al., 2009). According to Bishop et al., the Te Kotahitanga program provides a model for culturally responsive and relationship-based pedagogy by emphasizing its central notion of an effective teaching profile (ETP) concerning the teacher-student instructional relationships in the classroom. This ETP notion entails teachers' ability to demonstrate care about their students as culturally located human beings and seeks to create a secure learning environment for Māori students (Bishop, Berryman, Cavanagh, \& Teddy, 2009; Hynds et al., 2011).

Another contextual element relevant to this inquiry is how educational policy is managed and implemented. Education policy in NZ is implemented via a decentralized laissez faire approach that gives principals significant power over the instructional process through their positional authority (Timperley \& Robinson, 2003; Yukich \& Hoskins, 2011). Therefore, one would expect White NZ principals with cultural competency and instructional leadership prowess to be better positioned to use their self-managing authority to actively address the ethnically based achievement gaps in NZ's mainstream schools. 
A final relevant contextual consideration in this inquiry is the advent of the 2010 National Curriculum Standards in NZ. The National Standards "were introduced in 2010 as part of the Government's initiative to raise literacy and numeracy levels, and to lift student achievement" (Education Review Office, 2012 , p. 3). Furthermore, these Standards describe what primary and intermediate school students should know and be able to do in reading, writing, and mathematics at different points in their schooling. Therefore, as the Standards become institutionalized in the NZ's mainstream schools, principals are expected to continue innovating ways of enhancing Māori and Pasifika scholastic achievement.

\section{Conceptualizing the Inquiry}

\section{Purpose and Research Questions}

The purpose of this inquiry was to understand how a sample of White principals of mainstream schools navigate the complex intercultural educational policy environment to address the academic challenges of minority-culture students. The ultimate outcome of this inquiry was an emergent conceptual definition of culturally responsive instructional leadership (CRIL). To attain its purpose, the inquiry set out to address the following central questions:

1. What is the principals' understanding of culturally responsive instruction $(\mathrm{CRI})$ ?

2. What motivates the principals to adopt or implement $\mathrm{CRI}$ in their schools?

3. What purposeful actions do they take to support CRI in their schools?

4. What do they perceive as student outcomes of CRI?

5. What challenges do they face as culturally responsive instructional leaders?

\section{Conceptual Framework}

Conceptual perspectives from effective schools research (ESR) (Brookover et al., 1982; Edmonds, 1979; Lezotte, 1997; Lezotte \& McKee, 2006), namely, instructional leadership and culturally responsive instruction framed my inquiry. In the early 1980s, ESR confirmed that schools with strong instructional leadership could make a tangible difference in the academic lives of students at risk of scholastic failure such as minority-culture and socio-economically disadvantaged students (Sorenson, Goldsmith, Méndez, \& Maxwell, 2011). In his scholarship, Lezotte (1997) considered a school effective if all the students came to learn the specified curriculum regardless of social-cultural factors in their backgrounds. Furthermore, the effective school principal was expected to act as an instructional leader who persistently communicated and executed the mission of excellence to the school community (Hoy \& Hoy, 2006; Lezotte, 1997). 
In Western education systems serving historically minoritized groups such as Māori and Pasifika communities, instructional leadership is an ESR concept of utmost relevance. It refers to the various actions that a principal takes or delegates to others to enhance student learning and achievement (Duke, 2012; Flath as cited in Jenkins, 2009; Marks \& Printy, 2003). Scholarship from NZ (Bendikson, Robinson, \& Hattie, 2012) categorized the concept into direct and indirect instructional leadership. Direct instructional leadership focused on "the quality of teacher practice, including the quality of the curriculum, teaching and assessment, and the quality of teacher inquiry and teacher learning" (p. 4). On the other hand, Kleine-Kracht (as cited in Bendikson et al., 2012) observed that indirect instructional leadership created the conditions ensuring that school policies, routines, and resources were in place to support high-quality teaching and learning.

Conceptualizing instructional leadership as actions a principal takes to improve an underachieving school alludes to ideals of intentionality and purposefulness in the principal's leadership behavior. Jenkins (2009) observed that the principal as instructional leader was different from the traditional principal as school administrator who mainly preoccupied himself or herself with managerial duties. Rather, Jenkins argued that the principal as instructional leader purposefully made instructional quality the top priority of the school and attempted to bring that vision to realization. The purposeful instructional leader, realizing that he or she cannot attain the vision alone, should forge a partnership with teachers and enable a climate where instructional leadership flourishes and emerges spontaneously from teachers themselves (Hoy \& Hoy, 2006). Such a climate can create effective followership among the school community members and lead to improved students' learning (Crippen, 2012; Leithwood \& Wahlstrom, 2008).

The final relevant concept in this inquiry is culturally responsive instruction (CRI), also known as culturally responsive pedagogy, which refers to an instructional approach that uses the cultural knowledge, prior experiences, and performance, and learning styles of ethnically diverse students to make learning more appropriate and effective for them (Bevan-Brown, 2003; Castagno \& Brayboy, 2008; Gay, 2010; Ladson-Billings, 1995; Rios \& Stanton, 2011; Sheets, 2005; Sleeter \& Cornbleth, 2011). Instructional leadership should target classroom practices that recognize and promote diversity and equity, focus on differentiated instruction, and help teachers assume culturally responsive teaching strategies (Knapp, Mkhwanazi, \& Portin, 2012). Educators using CRI approaches teach to and through the strengths of diverse students; use varied teaching strategies; and attempt to bridge cultural differences by talking about individual differences among students and how these differences make for better learning (Gay, 2002, 2010; Sheets, 2005).

Extant CRI scholarship has often focused more on teachers' and students' characteristics and less on the role of instructional leaders. Therefore, this inquiry sought to contribute to the development of instructional leadership perspectives on CRI. With increasing emphasis placed on the National Curriculum Standards 
and the need for New Zealand's mainstream schools to better serve ethnic minority students, the under-researched concept of culturally responsive instructional leadership (CRIL) is more relevant than ever.

\section{Methodology}

I used naturalistic inquiry to describe, understand, and interpret experiences on the basis of my field-based research (Lincoln \& Guba, 1985) in three NZ schools. I used a multiple qualitative case study approach to study individual cases with multiple boundaries, clarifying understanding of a principal's unique school setting (Yin, 2003).

\section{Participant Recruitment and Ethics}

I used criterion sampling as a strategy to recruit participants that met predetermined criteria of importance to the inquiry (Patton, 2002). These included:

- Race and geography: i.e., the participants had to be White principals working and living in urban areas in the North Island where I was on a two-week field study and where my local educational informants confirmed a high population of Māori and adequate Pasifika communities for my study;

- Availability of participants for interviews and observations during the first two weeks in March 2012; and

- Extensive participant experience as a principal of a mainstream school with substantial numbers of socio-culturally disadvantaged students.

Participant recruitment processes led to the identification of three White male principals, including leaders of a primary school, an intermediate school, and a secondary school. As this study involved direct engagement with, and collecting data from, human subjects, I sought approval from, and followed the appropriate ethical procedures of, my institution's Committees on Human Research in order to protect the privacy and confidentiality of the participants and their respective school communities. I therefore used the following pseudonyms for the principals and their schools: Principal McKinnon (Tionga Primary School), Principal Burck (Toroa Intermediate School), and Principal Foster (Tohunga High School). Table 1 provides information about the participants, their professional experience, and the school they served at the time of the study. 
Table 1. Research Participants and Settings

\begin{tabular}{|c|c|c|}
\hline Participant & Participant's Experience & School Characteristics \\
\hline $\begin{array}{c}\text { Principal } \\
\text { McKinnon, } \\
\text { Tionga Primary } \\
\text { School }\end{array}$ & $\begin{array}{l}\text { Has been in education for } 35 \\
\text { years: first as a teacher, then } \\
\text { deputy principal, and finally a } \\
\text { principal at Tionga for } 17 \\
\text { years }\end{array}$ & $\begin{array}{l}\text { Co-educational; } 400 \text { Year } 1-6 \text { students } \\
\text { (85\% Māori, } 12 \% \text { Pākehā, and } 2-3 \% \\
\text { Pasifika); and a decile rank of } 1(a)^{4} \text {, } \\
\text { implying that the school draws most of } \\
\text { its funding from MOE. }\end{array}$ \\
\hline $\begin{array}{c}\text { Principal } \\
\text { Burck, Toroa } \\
\text { Intermediate } \\
\text { School }\end{array}$ & $\begin{array}{l}\text { Has been in education for } 36 \\
\text { years: first as a teacher, then } \\
\text { a teaching principal and } \\
\text { advisor mentoring principals, } \\
\text { and finally a principal at } \\
\text { Toroa for } 18 \text { years }\end{array}$ & $\begin{array}{l}\text { Co-educational; } 426 \text { Year } 7-8 \text { students } \\
\text { ( } 78 \% \text { Māori, } 19 \% \text { Pākehā and } 3 \% \\
\text { Pasifika); and a decile rank of } 2 \\
\text { implying that the school gets } \\
\text { substantial financial support from } \\
\text { MOE. }\end{array}$ \\
\hline $\begin{array}{c}\text { Principal } \\
\text { Foster, } \\
\text { Tohunga High } \\
\text { School }\end{array}$ & $\begin{array}{l}\text { Has been an educator for } 32 \\
\text { years: began as teacher, } \\
\text { then assistant principal, and } \\
\text { finally now a principal at } \\
\text { Tohunga for } 16 \text { years }\end{array}$ & $\begin{array}{l}\text { Boys only; } 800 \text { Year } 9-13 \text { students } \\
\text { (65\% Māori, } 25 \% \text { Pākehā, and } 10 \% \\
\text { Pasifika); and a decile rank of } 3 \\
\text { implying that, on average, the students } \\
\text { are drawn from socio-economically } \\
\text { slightly better-off families than Tionga } \\
\text { primary and Toroa intermediate } \\
\text { schools. }\end{array}$ \\
\hline
\end{tabular}

\section{Data Collection Procedures}

I began the inquiry by extensively reviewing literature on NZ's public school system, curriculum and instruction, schooling outcomes of minority students, and the participants' individual schools. During my two-week fieldwork, I initially held and recorded a face-to-face 60-90 minute semi-structured interview with each principal. From these interviews I sought to understand the principals' backgrounds and experiences in teaching and instructional leadership, and their knowledge and understanding of CRI. I also sought to understand what motivated the principals to implement what these leaders understood as CRI and how their schools engaged with their definitions. Most importantly, I sought to understand the intentional actions the principals had taken to enhance achievement of minority-culture students, as well as the schooling outcomes that the principals attributed to their actions.

Much as I primarily paid attention to the principals' voice in this inquiry, I was aware of the limitations of participants' voice as a single source of data (Jackson \& Mazzei, 2009). I therefore supplemented interviews by observing two integrated classes taught by Pākehā teachers in each of the schools and an integrated co-curricular cultural activity, the haka powhir ${ }^{5}$, at Toroa Intermediate School. I also reviewed school artifacts (e.g., mission statements and policy documents); held informal conversations with teacher leaders; and had an overnight visit at a marae, a Māori cultural center with strong connections to the schools. The visit at the marae enabled me to interact with community members 
and obtain their views about the principals' leadership actions. The secondary data collection techniques enabled me to confirm the information that I had initially obtained from the principals. I then returned to the primary participants and held two follow-up face-to-face conversational interviews with two of the principals and a telephone conversational interview with the third principal, in order to obtain supplementary information about the questions that emerged from my interactions with secondary data sources.

\section{Analysis Procedures}

I conceived data analysis as "a process of resolving data into its constituent components to reveal their characteristic themes and patterns" (Coffey \& Atkinson, 1996, p. 8). To analyze the data (transcribed interviews and observational notes), I therefore conducted inductive coding exercises to identify emergent themes, which led me to meaningful categories and general observations (Creswell, 2007). I then summarized themes, broad categories, and general observations in three tables corresponding to the three principals and their schools. I finally emailed these analyzed data tables to the principals and followed up with telephone calls to explain analytical procedures, obtain feedback, and validate initial findings.

\section{Findings}

In this section I present findings in four general themes that emerged naturally from my data analysis. These themes include: principals' perceptions of $\mathrm{CRI}$; motivation for $\mathrm{CRI}$; purposeful actions; and perceived outcomes of $\mathrm{CRI}$ practices and challenges.

\section{Principals' Perceptions of CRI}

The three principals articulated similar knowledge, understanding, and awareness of CRI. To Principal McKinnon, CRI meant fostering a bicultural learning environment. It also meant recognizing and valuing both Māori and Pākehā cultures in curriculum and instruction. This interpretation is supported by his statement: "We bring into the curriculum aspects of both Māori and Pākehā cultures, so it becomes a positive bicultural learning environment." CRI meant to Principal Burck maintaining a safe school environment that values the culture of ethnic minority students as well as building instruction upon the culturally founded strengths of these students. To Principal Foster, CRI meant treating each student as an individual with a unique culture, and teaching to students' strengths.

\section{Motivation for Culturally Responsive Instruction}

The three principals demonstrated similar sources of motivation to implement what they understood as CRI. Principal McKinnon's early exposure and appreciation of Māori culture and his passion for children's learning were the 
strongest rationales for practicing what he defined as CRI. Principal McKinnon stated how his early exposure to Māori culture was a significant source of motivation:

I grew up with very good friends who were Māori and who immersed me in Māori culture...But I also took interest in it, because I respect Māori people. And I really took on their Tikanga (customs and practices), and I live them, day in and day out. So there are these things that are part of their upbringing that I find important for all people in New Zealand to know.

Principal McKinnon reported having been aware of the Ka Hikitia strategy and the Pasifika Education Plan. While he appreciated the content and philosophy behind these policy documents, he stated that his school had already been practicing the tenets, specifically those in the Ka Hikitia strategy such as teaching to students' strengths and structuring the classroom along the Māori whanau ${ }^{6}$ concept. In one of my two observations at Tionga Primary, I witnessed a Pākēha Year 3 teacher deliberately implementing this CRI technique in a literacy (reading) class in which students in groups took turns to read to and ask each other comprehension questions. All students appeared enthusiastic about the literacy lesson.

Principal Burck's strongest source of motivation to adopt CRI was what he called his core value of educating all children equitably. His value orientation was enhanced by his extensive experience in education, his exposure to Māori and Pasifika cultures both in his own family and beyond, and having many members of the teaching staff that were willing to follow his culturally responsive instructional leadership actions. Principal Burck acknowledged the existence of policies such as Ka Hikitia or Pasifika Education strategies but insisted that they were only secondary sources of motivation:

It certainly was not prompted by a policy from the Ministry, even though we certainly have an old policy called the Treaty of Waitangi, which is an umbrella to everything in New Zealand. To me coming to a school and community like this one, I think you shift your values quite a lot. So where I started in 1982 as a principal is very different from where I am sitting in 2012. In 1982, you tended to be very black and white. It has to be done this way because the regulations said you have to do it that way. You were asking me this morning how we go about enrolling children of parents in illegal immigration status. In 1982, I would have said, "I can't enroll any such children because this is what the regulations say." In 2012, I say to such children, "Come and let's find a way around this problem. You need to be at school and we need to find a way of giving you an opportunity to learn like all other children."

The major sources of motivation for Principal Foster to practice CRI were his unforgettable high school experience with a teacher who punished him for having disagreed with what he called his teacher's racist views; his passion for teaching and mentoring boys; his early exposure to role models; his belief that 
$\mathrm{CRI}$ aligned with the Treaty of Waitangi; and his belief that success for all students was a deliberate government policy.

\section{Purposeful Actions}

The principals took both similar and varying actions aimed at valuing the culture and enhancing the learning of ethnic minority students. Principal McKinnon purposefully worked to maintain the mainstream identity of the school in a balance, which he said was in line with the official ideals of biculturalism of modern New Zealand society:

At our school I have made sure that we are not trying to teach exclusively to Pākehā students or teach exclusively to students who are Māori. But I have made sure we bring in aspects of both cultures, so it becomes a bicultural learning environment.

Among other actions, Principal McKinnon mentored teachers and ensured that they made a deliberate effort to understand Māori cognitive styles and planned to deliver instruction accordingly. I confirmed this practice in two class observations where I witnessed two Pākehā female teachers using differentiated teaching techniques. These included Māori and a few Pasifika and Pākehā student groups cooperatively working together to solve mathematics problems and other students who preferred to work independently on the same tasks who happened to be Pākehā. From my conversations with these teachers, I learnt that they had received ongoing supervisory and mentoring support from Principal McKinnon. Principal McKinnon also deliberately offered aspects of Mãori culture such as the haka powhiri in a compulsory manner with exemptions made to a few students for religious reasons. He stated that he had not done a lot to integrate the cultural considerations of Pasifika students due to their relatively low enrollment.

Principal Burke made a conscious effort to advocate for Māori students and mentor Pākehā teachers on cultural competency by sharing with them his understanding of Māori cultural practices and how they relate to schooling:

I spend a lot of time talking with teaching staff and working with them through CRI strategies. Every day has to be a new day. No matter what happened today, when those children walk in to school tomorrow, it must be a new day for them. Our children should feel that even if I blew it today, but tomorrow I have to come to school. Just a simple thing like, our children often go to a tangi (funeral). Their families are pretty much extended families. Often times Māori children are raised by their uncles, aunties, cousins, etc., who they may call mum in their culture. So when a child says to the teacher, "I am going to my uncle or auntie," a teacher who may question why the Māori student must miss school and go to a tangi of a deceased uncle for a number of days and might not understand that the Māori student lost a "mum" or a "dad" and therefore needed several days to recover from the loss.

On the same idea of advocacy for Māori students and educating teachers about Māori cognitive styles, Principal Burck stated how a simple action like 
abolishing school bells was culturally and pedagogically meaningful to Māori students:

The second one as silly as it sounds, I abolished bells, because many of our Māori students have to walk to school after walking their brothers and sisters to school who start school after us. The problematic question for them is, "Do I get to school too early for my little brother and sister, or do I get to school late for me?" By removing the bell, you are not putting the mark on the child. So I have tried to work with teachers on how to deal with lateness. Rather than greeting the Māori child with "You are late again." How about approaching the issue from this angle: "Hello Vincent, here is where we are at in Math"? But then later on in the day, the teacher can approach the student and talk about the lateness and see where the problem lies. Our children get very whakamä (shy or easily shamed), and once they are ashamed they have a hard time coming back. So across the school, we have to constantly discover ways to engage with our Māori students in culturally responsive ways.

Principal Burck also introduced special learning centers with the deliberate aim to use them to orient curriculum and instruction towards students' perceived strengths:

Our learning centers acknowledge that students bring to school their culturally unique strengths. So we are able to talk to the students about what their perceived strengths are, and how the centers can best serve them. I tend to believe that if you feel strong about something, then you don't fear it, and you excel at it.

For example, students with perceived strength in the arts were taught the mainstream curriculum from an artistic perspective, and those with perceived strengths in technology, sports, and academics learnt the mainstream curriculum from those perspectives. From my observations of two learning center-based instructional activities, I witnessed Māori, Pasifika, and Pākehā students actively engaged, particularly in their digital literacy and in dance and drama projects.

Other intentional actions by Principal Burck included giving parents and the community voice to decide the cultural agenda in the curriculum:

For instance, yesterday I took you to the marae where you met with Māori elders. When I meet with such Māori community members and we exchange ideas about the needs of our community, this contributes to the way we do things at our school. So you gotta have those links with the community. Every principal needs those links, and if you think you can sail solo, I think you are a fool.

Furthermore, Principal Burck reported using his positional authority to address the needs of families in difficult situations. To specifically meet Pasifika student needs, Principal Burk established and maintained a core team of three Pasifika teachers, one of whom is a senior teacher leader. In my conversations with the 
Pasifika teacher leader, she informed me that her team spent considerable time reaching out to Pasifika families to address matters of their children's schooling.

Principal Foster reported a few actions he deliberately took at Tohunga High. He worked with the school community to transform the culture at Tohunga High and to focus it on the scholastic success of Mãori students through the implementation of Te Kotahitanga. With discretionary funding from MOE and private sources, he established a professional learning resource center at the school with a full-time team that provided in-service support and mentoring to teachers on CRI. In his science teaching, he personally endeavored to apply tuakana teina, a Māori pedagogical philosophy where older and younger siblings take turns sharing expertise and helping each other in the learning process. While I could not observe his class due to scheduling challenges, in one of my two class observations at Tohunga High I witnessed the application of tuakana teina in a Year 10 art class where Year 11 students were supporting Year 10 students working on whakairo (Māori carvings).

Principal Foster of Tohunga High also reported his deliberate action to encourage Māori students to be proud of their cultural identity because many of them had internalized a negative feeling about their language.

I once decided to introduce Te Reo Māori classes to our students. That never worked. There was too much resistance from both non-Māori and Māori students. Later I decided, I would make a language compulsory at Year 9, semi-compulsory at Year 10, and made French and Te Reo Māori the language options. That never solved the problem either. The French class was booming while the Te Reo Mãori class was pretty empty. So the next thing I did, I would initiate whakairo (Māori carvings) and performing arts, and that way I would keep the Te Reo Māori teacher that I had hired, but in order to do whakairo, or Māori performing arts, you would need to do a unit or an achievement standard in Te Reo Mãori. Since Whakairo and Māori performing arts are popular, that would be the only way students would be attracted to learning Te Reo Māori.

The three principals took the $\mathrm{CRI}$ actions presented above intentionally to address the scholastic challenges of minority-culture students. They also shared their perceived outcomes of their deliberate actions, and related challenges.

\section{Perceived Outcomes of CRI Practices and Challenges}

Although the three principals worked at three different levels of schooling with varying curricular expectations, the outcomes they attributed to their actions are similar in nature. They all believed that, in their schools, the Māori learners in particular became more motivated and academically engaged than before. Regarding challenges, all the principals expressed some degree of concern about followership among their staff, which initially slowed down the process of institutionalizing $\mathrm{CRI}$ practices. 
Principal McKinnon reported that the children were learning from their strengths, were finding schooling more interesting, and were more engaged than before. On the notion of followership, Principal Mckinnon stated:

Yes, and we have had cases of both extremes, where some teachers have wanted our school to almost go the whole hog [meaning offer a lot more Māori culture and activities), yet I have had to set them back by saying remember we are a mainstream school. As for our teachers, I don't know of many that are currently not collaborative in a cultural sense. We did have some, but they have since departed.

Regarding challenges, Principal McKinnon expressed dissatisfaction with MOE for not accompanying the Ka Hikitia strategy with adequate professional development for his school. He also expressed the following strong concerns about the new National Standards for students in Years 1-8.

My fears are that many of our Māori students are starting school far behind in their education. And I can see things like National Standards undoing what we have been doing with them, discouraging them because they will get reports that they are below National Standards, below expected levels. In some cases, that creates a feeling of failure and cause further failure. The pedagogy behind national standards doesn't suit their style of learning. National Standards are too Europeanized for a lot of our Māori students.

Principal Burck affirmed his belief that his deliberate $\mathrm{CRI}$ actions contributed to the improvement in academic engagement of Māori and Pasifika students. He stated:

I sincerely believe our strategies have worked effectively. We all see the results. The children are more engaged at school. They like what they are doing. We have moved a lot of children from one point to another in terms of achievement. We want them to make more gains, but the barriers to their achievement may be a little bit bigger than we anticipated.

On the notion of followership, Principal Burck stated, "Well, I wouldn't say that all staff are good followers on CRI, but I think I have got a hard core majority of staff right behind this agenda." The key challenge for Principal Burck was what he called the pervasive problem of child abuse in the community, which negatively influenced the learning environment at school.

Principal Foster expressed strong belief that the school reculturing efforts had yielded important outcomes for Māori and Pasifika students including their improved academic engagement. He measured this outcome by the Māori and Pasifika students' improvements in school retention and completion with better academic qualifications. While Principal Foster was hopeful for the future of Māori and Pasifika students' scholastic success, he also encountered several challenges. One of the challenges was the existence of non-followers among his teaching staff, both Māori and non-Māori teachers, who initially believed that the 
Te Kotahitanga project was racist and political in nature, thereby slowing down progress. Principal Foster observed:

So in terms of followership, there are 60 teaching staff, and another 20 support staff, and one of the hardest stuff that I hate to deal with, but it's there, is that there is always going to be one, or two, or three that won't get on board. Initially about $20 \%$ of our teachers, the majority of them nonMāori thought Te Kotahitanga was racist as it targeted Māori, and surprisingly three of them were Māori who thought Te Kotahitanga was purely political.

His other challenge was the difficulty for teachers to balance the use of $\mathrm{CRI}$ strategies such as tuakana teina with the academic rigors of NCEA in Years 1113. Furthermore, he reported that the frequent use of academic jargon in the CRI resources within Te Kotahitanga documents was challenging and slowed down teachers' interpretation and application. Another challenge was the inadequacy of financial resources to sustain Te Kotahitanga, which he hoped would come to define the school culture at Tohunga High. The findings presented above have implications for the theory and practice of CRI, discussed below.

\section{Discussion and Conclusion}

This inquiry confirmed that the principals navigated a complex intercultural educational policy environment in New Zealand, a country that continues to struggle with the legacies of colonialism and the corollary effects of globalization. They displayed a rich understanding of CRI. The CRI perspectives of the Toroa and Tohunga principals aligned with Gay (2002) who defined CRI as "using the cultural characteristics, experiences, and perspectives of ethnically diverse students as conduits for teaching them more effectively" (p.106). On the other hand, the biculturalist perspective of the Tionga principal aligned less with Gay's $\mathrm{CRI}$ concept, and more with multicultural education as a tool for fostering crosscultural understanding and respecting one another's culture in education (Gibson as cited in Banks \& Banks, 1993; Özturgut, 2011; Rios \& Stanton, 2011).

This inquiry purposefully focused on White principals to understand cultural competency (Diller \& Moule, 2005) and how they used positional authority to actively address scholastic challenges of minority-culture students. The findings confirmed that the principals were not only culturally competent, but they also used their instructional authority (Timperley \& Robinson, 2003; Yukich \& Hoskins, 2011) to foster minority culture students' engagement.

This inquiry suggests that White principals in similar situations, who have grown up in multicultural settings and worked within an enabling bicultural/multicultural educational policy environment, may be motivated to become culturally responsive instructional leaders. However, taking heed that "leadership and followership fundamentally depend on one another for any meaning at all" (Leithwood \& Wahlstrom, 2008, p. 455), this inquiry suggests that culturally responsive instructional leaders would not meet their instructional goals 
for socio-culturally disadvantaged students without successfully rallying for support and engaging various agents in the school community such as teachers, parents, cultural leaders and policy makers. Therefore principals ought to engage in direct and indirect instructional leadership activities (Bendikson, Robinson, \& Hattie, 2012) that empower and enable teachers, in particular, to practice effective culturally responsive instruction.

This inquiry revealed that the instructional leaders' actions were more oriented towards Māori learners than Pasifika students. This is perhaps because of the daunting history of Mãori underachievement; the evident education policy pressures designed to address this historical phenomenon; and the fact that the Māori population is far higher than Pasifika students, whose academic achievement is relatively stronger than that of Māori students at the national scale (MOE, 2009). The inquiry also suggested that CRI was a more challenging practice in the one high school where children were older and were expected to grasp a lot of disciplinary content in order to pass exams and obtain academic qualifications such as NCEA. This may be an opportunity for future action research to explore the applicability of indigenous $\mathrm{CRI}$ strategies such as Tuakana Teina in high-stakes schooling environments where emphasis is more on rigorous academic content and related measurement, and less on student engagement (Padilla, 2010).

As the findings revealed, purposefulness (Jenkins, 2009), consciousness, intentionality, creativity, and collaboration about strategies to address the academic challenges of minority-culture students must be embedded in instructional leadership for that leadership to be culturally responsive. Instructional leadership in intercultural educational settings is not automatically culturally responsive. A noteworthy design issue relevant to the above observation is that the criterion sample in my inquiry would have benefited from a greater diversity in terms of gendered perspectives on CRI. However, since extant literature (Bevan-Brown, 2003; Castagno \& Brayboy, 2008; Gay, 2002, 2010; Ladson-Billings, 1995; Sleeter \& Cornbleth, 2011) has not confirmed any particular gender-based differences in the practice of $\mathrm{CRI}$, I did not expect this limitation to have important implications on the emergent CRIL concept. A related limitation is that I only studied perspectives of White school leaders. Therefore my intentional focus on White principals does not provide context to local school leaders of color: i.e., Māori and Pasifika principals or principals of Asian descent.

From this inquiry, the emergent conceptual definition of culturally responsive instructional leadership entails those purposeful, well-intentioned, creative, and collaborative actions that a principal takes to enhance the academic engagement and achievement of minority-culture students. Such actions may include motivating teachers to teach students to their culturally founded strengths and cognitive styles and value minority-students' cultures and their pedagogies as well as keep those cultural assets alive and active in curriculum and instruction. They may also include providing ongoing professional learning opportunities for teachers, mentoring them to adopt $\mathrm{CRI}$ as effective classroom practices and actively engaging the community in the schooling of minority- 
culture children. The findings of this study and the CRIL concept, in particular, cannot be generalized beyond the three participants. However, the CRIL concept offers guidance on how instructional leaders may position themselves to engage minority-culture students operating in educational systems that adhere to Western ways of knowing. Therefore the CRIL concept has transferable value in education systems of countries such as Australia, Brazil, Canada, and the United States, which have colonial histories and effects of globalization similar to those of New Zealand. In short, this study reminds educational leaders of the importance of adopting CRIL in intercultural educational policy settings.

\section{Notes}

1. According to Sibley, Robertson, and Kirkwood (2005), biculturalism in the NZ context refers to the ideal or social value of a partnership between Māori (the indigenous peoples of NZ) and Pakeha (New Zealanders of European descent), which is deemed fair and equitable by both parties.

2. Ka Hikitia, in Māori languages, means to step up, to lengthen one's stride, so the Ka Hikitia strategy is about ensuring that all Maori students reach their highest potential.

3. The NZ public school system (MOE, 2008) consists of three major school categories: primary schools, intermediate schools, and secondary schools. Primary schools are structured around two concepts: contributing primary schools (year 1 - year 6 ) that are attended by students aged between five and ten years or full primary schools (year 1 - year 8) that are attended by students aged between five and twelve years. The final two years of a full primary school are frequently structured separately in what is known as an intermediate school. Secondary/high schools or colleges (year 9 - year 13) are generally attended by students aged between 13 and 17 years.

4. MOE uses a decile ranking system (1-10) to determine the extent to which a school draws its students from low socio-economic communities. Decile 1 schools are the $10 \%$ of schools with the highest proportion of students from low socio-economic communities, whereas decile 10 schools are the $10 \%$ of schools with the lowest proportion of these students. MOE clarifies that a decile does not indicate the overall socio-economic mix of the students attending a school or measure the standard of education delivered at a school. The lower the decile rank, the larger the operational funding grant from the MOE.

5. A vibrant Māori ceremonial dance of welcome, but with the initial intention of intimidating the guests

6. Idea of a large/extended family working together in groups 


\section{References}

Banks, J., A, \& Banks, C. A. (1993). Multicultural education: Issues and perspectives. Boston, MA: Ally and Bacon.

Bendikson, L., Robinson, V., \& Hattie, J. (2012). Principal instructional leadership and secondary school performance. SET: Research Information for Teachers, 1(1), 2-8.

Bevan-Brown, J. (2003). The cultural self-review: Providing culturally effective, inclusive, education for Māori learners. Wellington, NZ: New Zealand Council for Educational Research.

Bishop, R. (2003). Changing power relations in Education: Kaupapa Maori messages for "mainstream" education in Aotearoa/New Zealand. Comparative Education, 39(2), 221-238.

Bishop, R., Berryman, M., Cavanagh, T., \& Teddy, L. (2009). Te Kotahitanga: Addressing educational disparities facing Maori students in New Zealand. Teaching and Teacher Education, 25(1), 1-9.

Brookover, W. B., Beamer, L., Efthim, H., Hathaway, D., Lezotte, L., Miller, S., Tornatzky, L. (1982). Creating effective schools: An in-service program for enhancing school learning climate and achievement. Holmes Beach, FL: Learning Publications.

Castagno, A. E., \& Brayboy, B. M. J. (2008). Culturally responsive schooling for indigenous youth: A review of the literature. Review of Educational Research, 78(4), 941-993.

Coffey, A., \& Atkinson, P. (1996). Making sense of qualitative data: Complementary research strategies. Thousand Oaks, CA: SAGE.

Creswell, J., W. (2007). Qualitative inquiry \& research design: Choosing among five approaches (2nd ed.). Thousand Oaks, CA: Sage Publications.

Crippen, C. (2012). Enhancing authentic leadership-followership: Strengthening school relationships. Management in Education, 26(4), 192-198.

Diller, J., \& Moule, J. (2005). Cultural competence: A primer for educators. Belmont, CA: Thomas/Wadsworth.

Duke, D. L. (2012). The judgment of principals. In B. G. Barnett \& A. R. Shoho (Eds.), The changing nature of instructional leadership in the 21st century (pp. 13-32). Charlotte, NC: Information Age Publishing.

Edmonds, R. (1979). Effective schools for the urban poor. Educational Leadership, 37(1), 15-24.

Education Review Office. (2012). Reporting to parents: National standards years 4 to 8 (pp. 1-7). Wellington, NZ: New Zealand Government.

Fletcher, J., Parkhill, F., Fa'afoi, A., Taleni, L. T., \& O'Regan, B. (2009). Pasifika students: Teachers and parents voice their perceptions of what provides 
supports and barriers to Pasifika students' achievement in literacy and learning. Teaching and Teacher Education, 25(1), 24-33.

Gay, G. (2002). Preparing for culturally responsive teaching. Journal of Teacher Education, 53(2), 106-116.

Gay, G. (2010). Culturally responsive teaching: Theory, research, and practice. New York, NY: Teachers College Press.

Hill, R. S. (2010). Fitting multiculturalism into biculturalism: Maori-Pasifika relations in New Zealand from the 1960s. Ethnohistory, 52(1), 292-319.

Howard, J. (2010). The value of ethnic diversity in the teaching profession: A New Zealand case study. International Journal of Education, 2(1), 1-22.

Hoy, A. W., \& Hoy, W. K. (2006). Instructional leadership: A research-based guide to learning in schools (2nd ed.). New York, NY: Pearson.

Hynds, A., Sleeter, C., Hindle, R., Savage, C., Penetito, W., \& Meyer, L. H. (2011). Te Kotahitanga: A case study of a repositioning approach to teacher professional development for culturally responsive pedagogies. Asia-Pacific Journal of Teacher Education, 39(4), 339-351.

Jackson, A. Y., \& Mazzei, L. A. (Eds.). (2009). Voice in qualitative inquiry: Challenging convential, interpretive, and critical conceptions in qualitative research. New York, NY: Routledge.

Jenkins, B. (2009). What it takes to be an instructional leader. Principal, 1, 34-37.

Knapp, M. S., Mkhwanazi, S. T., \& Portin, B. S. (2012). School-based instructional leadership in demanding environments: New challenges, new practices. In B. G. Barnett \& A. R. Shoho (Eds.), The changing nature of instructional leadership in the 21st Century (pp. 187-214). Charlotte, NC: Information Age Publishing.

Ladson-Billings, G. (1995). Toward a theory of culturally relevant pedagogy. American Educational Research Journal, 35(1), 79-85.

Leithwood, K., \& Wahlstrom, K. L. (2008). Linking leadership with student learning: Introduction. Education Administration Quarterly, 44(4), 455-457.

Lezotte, L. W. (1997). Learning for all. Okemos, MI: Effective School Products.

Lezotte, L. W., \& McKee, K. M. (2006). Stepping up: Leading in the charge to improve our schools. Okemos, MI: Effective Schools.

Lincoln, Y. S., \& Guba, E. G. (1985). Naturalistic inquiry. Beverly Hills, CA: Sage.

Marks, H. M., \& Printy, S. M. (2003). Principal leadership and school performance: An integration of transformational and instructional leadership. Educational Administration Quarterly, 39(3), 370-397.

May, S., \& Hill, R. (2005). Bilingual education in Aotearoa/New Zealand: At the crossroad. Paper presented at the Fourth International Symposium on Bilingualism, Sommerville, MA. Retrieved from http://www.lingref.com/isb/ 4/122ISB4.PDF 
Ministry of Education. (2007). The New Zealand curriculum. Wellington, New Zealand: Ministry of Education.

Ministry of Education. (2008). The New Zealand education system: An overview. Wellington, New Zealand: The International Division, Ministry of Education.

Ministry of Education. (2009). Education statistics of New Zealand: 2009. Wellington, New Zealand: Ministry of Education.

Ministry of Education. (2012a). Me Kōrero-let's talk: Ka hikitia-accelerating success 2013-2017 (pp. 1-32). Wellington, New Zealand: Ministry of Education.

Ministry of Education. (2012b). Pasifika Education Plan 2013-2017 (pp. 1-16). Wellington, New Zealand: Ministry of Education.

New Zealand Qualifications Authority. (2013). How NCEA (National Certificates of Educational Achievement) works. Retrieved from http://www.nzqa. govt.nz

Özturgut, O. (2011). Understanding multicultural education. Current Issues in Education, 14(2), 1-11.

Padilla, R. V. (2010). High-stakes testing and accountability as social constructs across cultures. In F. W. Parkway, G. Hass \& E. J. Anctil (Eds.), Curriculum Leadership: Readings for developing quality educational programs ( $9^{\text {th }}$ ed., pp. $\left.72-80\right)$. Boston, MA: Allyn \& Bacon.

Patton, M. Q. (2002). Qualitative research \& evaluation methods ( $3^{\text {rd }}$ ed.). Thousand Oaks, CA: Sage Publications.

Rios, F., \& Stanton, F. C. (2011). Understanding multicultural education: Equity for all students. New York, NY: Rowman \& Littlefield Education.

Sheets, H. R. (2005). Diversity pedagogy: Examining the role of culture in the teaching-learning process. New York, NY: Pearson.

Sibley, C. G., Robertson, A., \& Kirkwood, S. (2005). Pakeha attitudes toward the symbolic and resource-specific aspects of bicultural policy in New Zealand: The legitimizing role of collective guilt for historical injustices. New Zealand Journal of Psychology, 34(3), 171-180.

Sleeter, C. E., \& Cornbleth, C. (2011). Teaching with vision: Culturally responsive teaching in standards-based classrooms. New York, NY: Teachers College Press.

Smith, J. (2010). Biculturalism and multiculturalism: Competing tensions in visual arts education in Aotearoa-New Zealand. International Journal of Multicultural Education, 12(2), 1-17.

Smits, K. (2011). Justifying multiculturalism: Social justice, diversity and national Identity in Australia and New Zealand. Australian Journal of Political Science, 46(1), 87-103. 
Sorenson, R. D., Goldsmith, L. M., Méndez, Z. Y., \& Maxwell, K. T. (2011). The principle's guide to curriculum leadership. Thousand Oaks, CA: Corwin, A SAGE Company.

Statistics New Zealand. (2006). Profile of New Zealander responses, ethnicity question: 2006 Census (pp. 1-23). Wellington, New Zealand: Statistics New Zealand.

Timperley, H. S., \& Robinson, V. M. J. (2003). Partnership as an intervention strategy in self-managing schools. School Effectiveness and School Improvement, 14(3), 249-274.

Tuuta, M., Bradnam, L., Hynds, A., Higgins, J., \& Broughton, R. (2004). Evaluation of the Te Kauhua Maori Mainstream Pilot Project: A report to the New Zealand Ministry of Education (pp. 1-81). Wellington, New Zealand: Ministry of Education, Maori Education Research.

Yukich, R., \& Hoskins, T., K. (2011). Responsibility and the other: Cross-cultural engagement in the narratives of three New Zealand school leaders. Journal of Systemic Therapies, 30(3), 57-72. 